\title{
Alpha-glucosidase inhibitors and risk of cancer in patients with diabetes mellitus: a systematic review and meta-analysis
}

\author{
Yiming Zhao ${ }^{1, *}$, Yongjian Wang ${ }^{1, *}$, Hanyu Lou ${ }^{1}$ and Lizhen Shan ${ }^{1}$ \\ ${ }^{1}$ Department of Endocrinology and Metabolism, the Second Affiliated Hospital Zhejiang University College of Medicine, \\ Hangzhou, Zhejiang, China \\ * These authors have Contributed equally to this work
}

Correspondence to: Yongjian Wang, email: dr.wyj@163.com

Keywords: alpha-glucosidase inhibitor, diabetes mellitus, cancer risk, meta-analysis, systematic review Received: January 25, $2017 \quad$ Accepted: April 17, $2017 \quad$ Published: April 28, 2017

Copyright: Zhao et al. This is an open-access article distributed under the terms of the Creative Commons Attribution License 3.0 (CC BY 3.0), which permits unrestricted use, distribution, and reproduction in any medium, provided the original author and source are credited.

\section{ABSTRACT}

Several studies have shown that anti-diabetic medications may modify the risk of cancer. We performed a systematic review and meta-analysis to evaluate the effect of alpha-glucosidase inhibitors (AGIs) on the risk of cancer in patients with diabetes mellitus. We conducted a systematic search of Medline, EMBASE, and Web of Science databases, up to September 30, 2016. Random-effects model was used to estimate the summary odds ratios (ORs) with $95 \%$ CI. Twenty-five studies (14 cohort, 7 case-control, and 4 randomized controlled trials) involving 1,285,433 patients with diabetes were included. Meta-analysis of observational studies showed that the use of AGIs was associated with a lower risk of developing cancer (OR $=0.86,95 \%$ CI 0.78-0.96), especially gastrointestinal cancer $(O R=0.83,95 \%$ CI 0.71-0.97). There was considerable heterogeneity across the studies introduced partly by the quality of included studies and adjustment for potential confounders. Meta-analysis of randomized controlled trials did not reveal any significant association between AGIs and cancer risk. Meta-analysis of observational studies indicated that AGIs may decrease the risk of cancer in individuals with diabetes.

\section{INTRODUCTION}

Diabetes mellitus (DM) is a prevalent disease associated with considerable global health burden [1]. The number of patients with DM has significantly increased in the past few decades globally, especially in China [2, 3]. As DM is considered a risk factor for several types of cancer $[4,5]$, anti-diabetic medications (ADMs) have the potential to modify the risk of cancer [6,7]. Metformin, an ADM, has been shown to exert antineoplastic effects through both insulin-dependent and insulin-independent mechanisms [8, 9]. However, data from various studies analyzing the anticancer effects of other types of ADMs, such as insulin, sulfonylureas, thiazolidinediones, alphaglucosidase inhibitors (AGIs), dipeptidyl peptidase-4 inhibitors, glinides, glucagon-like peptide-1 (GLP1) agonists, and sodium glucose cotransporter type 2 inhibitors, are not consistent [7, 10-14]. AGIs such as acarbose, voglibose, and miglitol are commonly used oral hypoglycemic agents in China and other eastern Asian countries. The association between AGI and risk of cancer has been inconsistently reported.
A meta-analysis of 13 studies (6 case-control studies, 2 cohort studies, and 5 randomized controlled trials [RCTs]) published in 2015 concluded that AGI was associated with a significantly higher risk (10\%) of cancer [7]. The meta-analysis noted a significant risk in the casecontrol studies, but not in the cohort studies or RCTs, compared with risk in the control population [7]. However, the meta-analysis had several limitations such as a mixture of studies with observational studies and RCTs; a mixture of studies with different tumor types; small case numbers in most studies; and lack of differentiation between cases of type 1 and type 2 diabetes. Studies published after this meta-analysis also yielded inconsistent results. Most recently, a cohort study of DM patients in Taiwan showed that acarbose use reduced the risk of incident colorectal cancer in patients with diabetes in a dose-dependent manner [15], but a cohort study performed in Italy did not find any association between AGI use and cancer risk [16].

Our objective was to conduct a systematic review and meta-analysis of observational studies and RCTs to investigate the effect of AGI use on cancer risk in patients with DM. 


\section{RESULTS}

A total of 1399 unique studies were identified using the search strategy, of which 25 studies involving $1,285,433$ patients with DM fulfilled the inclusion criteria and were pooled in the meta-analysis (14 cohort, 7 casecontrol, and 4 RCTs) [15-39].

\section{Study characteristics}

The study characteristics are shown in Table 1 . The earliest study period began in 1989 and the latest period ended in 2015. Fifteen of these studies were populationbased studies, and the remaining 10 were hospital-based studies. Nineteen studies were from Asia and 5 studies were from Europe. One RCT was multicenter trial and included mixed populations (from China, Romania, and Spain). A majority of the included studies (22 studies) demonstrated cancer risk in patients with type $2 \mathrm{DM}$, and the remainders did not report the subtype of DM. Two studies assessed the modification of cancer risk with duration and dose of exposure to AGI $[15,34]$.

\section{Quality of included studies}

The median Newcastle-Ottawa quality score for the observational studies was 7 (range 5-8). Table 2 depicts the methodological quality of all observational studies.
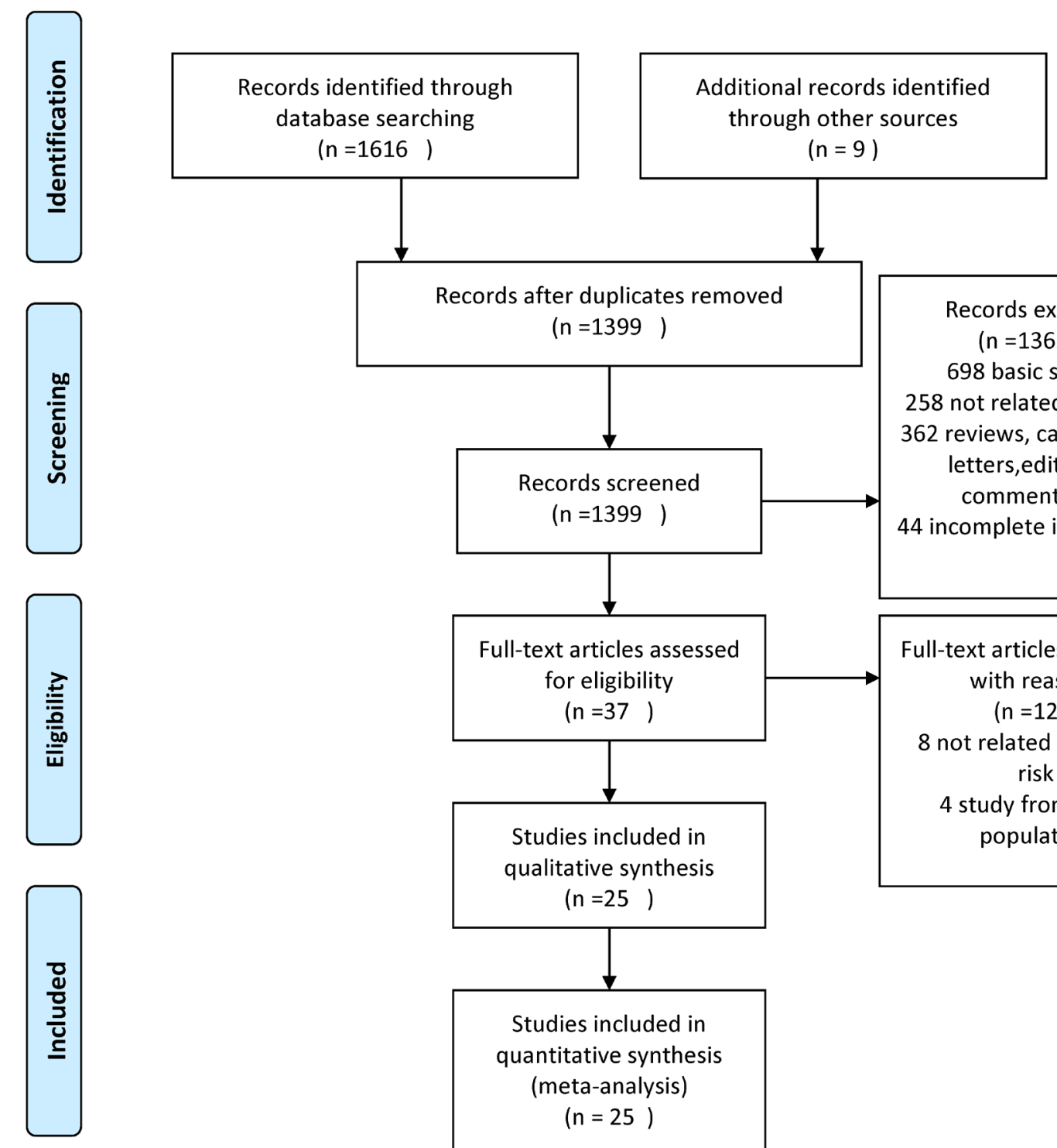

Records after duplicates removed

( $n=1399$ )

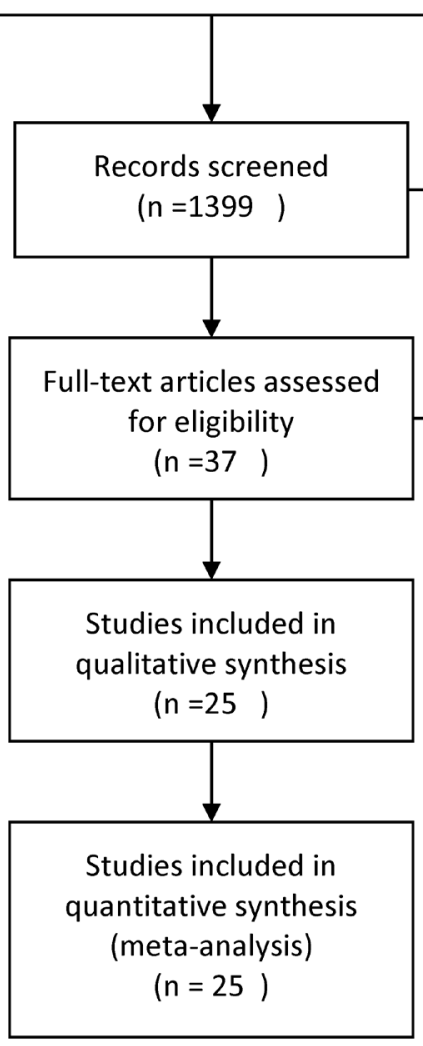

Records excluded

$(n=1362)$

698 basic science

258 not related to cancer

362 reviews, case-reports,

letters, editorials,

commentaries

44 incomplete information

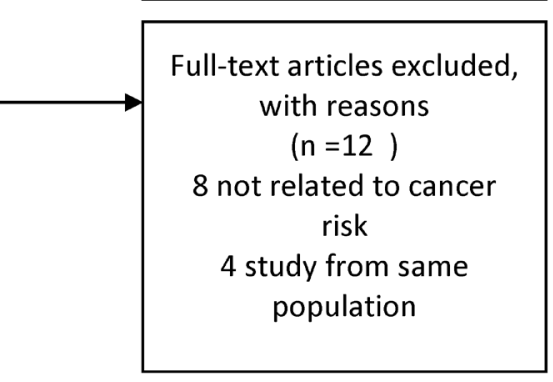

Figure 1: Study flow diagram in line with Preferred Reporting Items for Systematic Reviews and Meta-Analyses (PRISMA) recommendations. 
Table 1: Characteristics of included studies assessing the risk of cancer in patients with DM on AGI.

\begin{tabular}{|c|c|c|c|c|c|c|c|c|c|c|c|c|}
\hline Study & Design & $\begin{array}{l}\text { Location } \\
\text { setting }\end{array}$ & $\begin{array}{l}\text { Time period; } \\
\text { mean F/U (years) }\end{array}$ & $\begin{array}{l}\text { Sample size } \\
\text { (AGI/total) }\end{array}$ & $\begin{array}{l}\text { Type of } \\
\text { cancer }\end{array}$ & \begin{tabular}{|l|} 
Type \\
of \\
DM
\end{tabular} & \begin{tabular}{|l|} 
Mean \\
duration of \\
DM (years)
\end{tabular} & $\begin{array}{l}\text { Mean } \\
\text { age }\end{array}$ & $\begin{array}{l}\text { Type of } \\
\text { AGI }\end{array}$ & $\begin{array}{l}\text { Exposure } \\
\text { ascertainment }\end{array}$ & $\begin{array}{l}\text { Outcome } \\
\text { ascertainment }\end{array}$ & $\begin{array}{l}\text { Potential } \\
\text { confounders }\end{array}$ \\
\hline Nakamura, T[17] & RCT & Japan; HB & $\mathrm{NR} ; 1$ & $15 / 45$ & NR & 2 & 16.8 & 55.5 & voglibose & RCT & $\begin{array}{l}\text { Adverse event } \\
\text { review }\end{array}$ & NR \\
\hline Pan, C[18] & RCT & $\begin{array}{l}\text { China, } \\
\text { Romania, } \\
\text { Spain; HB }\end{array}$ & $\mathrm{NR} ; 0.5$ & $220 / 661$ & NR & 2 & 1.3 & 51.9 & Acarbose & RCT & $\begin{array}{l}\text { Adverse event } \\
\text { review }\end{array}$ & NR \\
\hline Kawaguchi, T[19] & $\mathrm{C}-\mathrm{C}$ & Japan; HB & $\begin{array}{l}\text { 2004.1-2008.12; } \\
\text { NR }\end{array}$ & $40 / 241$ & Liver & 2 & NR & 68.8 & NR & HDMS & $\begin{array}{l}\text { Medical record } \\
\text { review }\end{array}$ & NR \\
\hline Yang, X[20] & Cohort & \begin{tabular}{ll|} 
Hong & Kong; \\
HB
\end{tabular} & $\begin{array}{l}\text { 1996.12.1- } \\
\text { 2005.1.9; } 4.9\end{array}$ & $829 / 6103$ & NR & 2 & 6 & 57 & Acarbose & $\begin{array}{l}\text { Medical record } \\
\text { review }\end{array}$ & ICD-9 & NR \\
\hline Bosco, J. L[21] & $\mathrm{C}-\mathrm{C}$ & Denmark; PB & 1989-2008; NR & $204 / 4323$ & Breast & 2 & NR & NR & NR & $\begin{array}{l}\text { Prescription } \\
\text { databases }\end{array}$ & $\begin{array}{l}\text { ICD-8 or ICD- } \\
10\end{array}$ & NR \\
\hline Monami, M[22] & $\mathrm{C}-\mathrm{C}$ & Italy; HB & 1998-2007, 6.3 & $8 / 482$ & NR & 2 & 8.4 & 68.9 & Acarbose & $\begin{array}{l}\text { Medical record } \\
\text { review }\end{array}$ & ICD-9 & NR \\
\hline Tseng, C. H.[23] & Cohort & Taiwan; PB & 2003.1-2005.12; 3 & $\mathrm{NR} / 115731$ & Bladder & 2 & NR & NR & Acarbose & NHI database & ICD-9 & $1,2,3,7$ \\
\hline Tseng, C. H.[24] & Cohort & Taiwan; PB & 2003.1-2005.12; 3 & $\mathrm{NR} / 52131$ & Prostate & 2 & NR & NR & Acarbose & NHI database & ICD-9 & $1,2,3,7$ \\
\hline Chang, C. H.[25] & C-C & Taiwan; PB & $\begin{array}{l}\text { 2000.12.31- } \\
\text { 2007.12.31; } 7.9\end{array}$ & $3207 / 40969$ & Colon, Liver & 2 & New-onset & NR & NR & $\begin{array}{l}\text { Pharmacy } \\
\text { prescription } \\
\text { database }\end{array}$ & ICD-9 & NR \\
\hline Kawamori, R.[26] & RCT & Japan; HB & $2008-2010 ; 0.5$ & $162 / 561$ & NR & 2 & NR & 58.5 & voglibose & RCT & $\begin{array}{l}\text { Adverse event } \\
\text { review }\end{array}$ & NR \\
\hline Lai, S. W.[28] & Cohort & Taiwan; PB & 2000-2008; 9 & $4638 / 19624$ & Lung & 2 & New-onset & 56.4 & NR & NHI database & ICD-9 & $1,2,3$ \\
\hline Lai, S. W.[27] & Cohort & Taiwan; PB & 2000-2008; 9 & $4449 / 19349$ & Liver & 2 & New-onset & 56.4 & NR & NHI database & ICD-9 & $1,2,3$ \\
\hline Liao, K. F.[29] & Cohort & Taiwan; PB & 1998-2007; NR & $12301 / 49803$ & Pancreas & 2 & New-onset & 55.9 & NR & NHI database & ICD-9 & NR \\
\hline Tseng, C. H.[30] & Cohort & Taiwan; PB & 1996-2005; NR & NR/115928 & Thyroid & 2 & NR & NR & NR & NHI database & ICD-9 & $1,2,3,6,7$ \\
\hline Chen, Y. L.[31] & Cohort & Taiwan; PB & $2000-2008 ; 5.5$ & $4472 / 19625$ & Gastric & NR & New-onset & 56 & Acarbose & NHI database & ICD-9 & 1,2 \\
\hline Chiu, C. C.[32] & Cohort & Taiwan; PB & 2000-2007; 7 & $2918 / 39515$ & \begin{tabular}{|l|} 
Colon, \\
Esophagus, \\
Gastric, \\
Rectum, \\
Pancreas, \\
Liver
\end{tabular} & NR & New-onset & 58.52 & NR & NHI database & ICD-9 & $1,2,3$ \\
\hline Origasa $\mathrm{H},[33]$ & $\mathrm{C}-\mathrm{C}$ & Japan; HB & 2005-2011; NR & $26 / 95$ & Bladder & 2 & NR & 69 & NR & $\begin{array}{l}\text { Medical record } \\
\text { review }\end{array}$ & $\begin{array}{l}\text { Medical record } \\
\text { review }\end{array}$ & 1,6 \\
\hline Simo, R.[34] & $\mathrm{C}-\mathrm{C}$ & Spain; HB & 2008-2010; NR & $115 / 2438$ & NR & 2 & 6.4 & 72.0 & NR & $\begin{array}{l}\text { Pharmacy } \\
\text { prescription } \\
\text { database }\end{array}$ & ICD-10 & $1,4,5,6,8$ \\
\hline Chen, Y. C.[35] & Cohort & Taiwan; PB & $1998-2007 ; 2.5$ & $150 / 7325$ & NR & 2 & New-onset & 62.6 & Acarbose & NHI database & ICD-9 & $1,2,3,7$ \\
\hline Lin, C. M[36] & Cohort & Taiwan; PB & 2005-2010; NR & NR $/ 34823$ & \begin{tabular}{|l|} 
Lung, Liver, \\
Colorectal, \\
Breast, \\
Oral cavity, \\
Pancreas \\
\end{tabular} & 2 & New-onset & 54.26 & NR & NHI database & ICD-9 & $1,2,3,6$ \\
\hline Son, J. W.[37] & RCT & Korea; HB & $2008.2-2009.1 ; 0.3$ & $81 / 156$ & Gastric & 2 & 12.2 & 56.1 & voglibose & $\mathrm{RCT}$ & $\begin{array}{l}\text { Adverse event } \\
\text { review }\end{array}$ & NR \\
\hline Tseng, Y. H.[15] & Cohort & Taiwan; PB & $1998-2010 ; 3.4$ & $199296 / 398592$ & Colorectal & NR & New-onset & 54.1 & Acarbose & NHI database & ICD-9 & $1,2,3,6,7$ \\
\hline Valent, F.[16] & Cohort & Italy; PB & 2002-2014; NR & $\mathrm{NR} / 109255$ & \begin{tabular}{|l|} 
Esophagus, \\
Gastric, \\
Colon, \\
Rectum, \\
Liver, \\
Pancreas
\end{tabular} & 2 & NR & NR & NR & $\begin{array}{l}\text { Pharmaceutical } \\
\text { prescription } \\
\text { database, }\end{array}$ & ICD-9 & $1,2,6$ \\
\hline $\begin{array}{l}\text { Dabrowski, } \\
\text { M.[38] }\end{array}$ & C-C & Poland; HB & 1998-2015; NR & $32 / 406$ & NR & 2 & 10.7 & 67.1 & Acarbose & $\begin{array}{l}\text { Medical record } \\
\text { review }\end{array}$ & $\begin{array}{l}\text { Medical record } \\
\text { review }\end{array}$ & $3,4,6,7,8$ \\
\hline Tseng, C. H[39] & Cohort & Taiwan; PB & 1998-2009, NR & $47734 / 247252$ & Kidney & 2 & New-onset & NR & Acarbose & NHI database & ICD-9 & NR \\
\hline
\end{tabular}

RCT, randomized controlled trial; C-C, case-control; PB, population based; HB, hospital based; DM, diabetes mellitus; F/U, follow-up; ICD-8/9/10, International Classification of Diseases, Eighth/Ninth/Tenth Revision; NR, not reported; NHI, National Health Insurance in Taiwan; HDMS, HCV-related diabetes mellitus study in Japan.

Potential confounders: 1 - age; 2 - sex; 3 - comorbidities; 4 - smoking; 5 - alcohol; 6 - diabetes status, including DM duration, DM control, other ADM use; 7 - social status, including living region, occupation, and income; 8 - BMI.

The quality of the RCTs was moderate (Figure S1). The overall methodological quality of this body of evidence was moderate to high.

\section{AGI and the risk of any cancer}

Of the 25 studies ( 21 observational and 4 RCTs) that reported on the association between AGI use and cancer 
Table 2: Assessment of quality of included studies using Newcastle-Ottawa Scale

\begin{tabular}{|c|c|c|c|c|c|c|c|c|c|c|}
\hline \multicolumn{11}{|l|}{ Cohort study } \\
\hline & \multicolumn{4}{|l|}{ Selection } & \multirow{2}{*}{\begin{tabular}{|l|} 
Comparability \\
$\begin{array}{l}\text { Comparability } \\
\text { of cohorts on the } \\
\text { basis of design or } \\
\text { analysis }\end{array}$ \\
\end{tabular}} & \multicolumn{5}{|l|}{ Outcome } \\
\hline Study & $\begin{array}{l}\text { Representativeness } \\
\text { of the exposed } \\
\text { cohort }\end{array}$ & $\begin{array}{l}\text { Selection of the } \\
\text { non-exposed } \\
\text { cohort }\end{array}$ & $\begin{array}{l}\text { Ascertainment } \\
\text { of exposure }\end{array}$ & \begin{tabular}{|l|} 
Demonstration \\
that \\
outcome of of \\
interest was not \\
present at start \\
of the study \\
\end{tabular} & & $\begin{array}{l}\text { Assessment of } \\
\text { outcome }\end{array}$ & $\begin{array}{l}\text { Was follow-up } \\
\text { long enough for } \\
\text { the outcome to } \\
\text { occur? }\end{array}$ & $\begin{array}{l}\text { Adequacy } \\
\text { of follow } \\
\text { up of } \\
\text { cohorts }\end{array}$ & $\begin{array}{l}\text { Total } \\
\text { stars }\end{array}$ & $\begin{array}{l}\text { Risk } \\
\text { bias }\end{array}$ \\
\hline Yang, X[20] & * & * & * & * & $*$ & $*$ & $*$ & - & 7 & Low \\
\hline Tseng, C. H.[23] & * & * & * & * & $* *$ & * & - & * & 8 & Low \\
\hline Tseng, C. H.[24] & $*$ & $*$ & $*$ & $*$ & $* *$ & $*$ & - & $*$ & 8 & Low \\
\hline Lai, S. W.[28] & * & * & * & * & ** & $*$ & * & - & 8 & Low \\
\hline Lai, S. W.[27] & * & $*$ & $*$ & * & $* *$ & * & $*$ & - & 8 & Low \\
\hline Liao, K. F.[29] & * & $*$ & * & $*$ & $*$ & $*$ & * & - & 7 & Low \\
\hline Tseng, C. H.[30] & * & * & * & * & $* *$ & * & - & - & 7 & Low \\
\hline Chen, Y. L.[31] & $*$ & * & $*$ & $*$ & $* *$ & * & 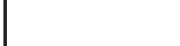 & - & 8 & Low \\
\hline Chiu, C. C.[32] & $*$ & $*$ & * & $*$ & $* *$ & $*$ & $*$ & - & 8 & Low \\
\hline Chen, Y. C.[35] & * & * & * & * & $* *$ & $*$ & - & $*$ & 8 & Low \\
\hline Lin, C. M[36] & $*$ & * & $*$ & $*$ & $* *$ & $*$ & - & - & 7 & Low \\
\hline Tseng, Y. H.[15] & $*$ & $*$ & $*$ & $*$ & $* *$ & $*$ & - & - & 7 & Low \\
\hline Valent, F.[16] & * & * & * & $*$ & $*$ & * & - & - & 6 & Moderate \\
\hline Tseng, C. H[39] & $*$ & $*$ & $*$ & $*$ & - & * & - & - & 5 & Moderate \\
\hline \multicolumn{11}{|l|}{ Case-control study } \\
\hline & \multicolumn{4}{|l|}{ Selection } & Comparability & \multicolumn{5}{|l|}{ Exposure } \\
\hline Study & $\begin{array}{l}\text { Is the case definition } \\
\text { adequate? }\end{array}$ & $\begin{array}{l}\text { Representativeness } \\
\text { of the cases }\end{array}$ & $\begin{array}{l}\text { Selection of } \\
\text { controls }\end{array}$ & $\begin{array}{l}\text { Definition of } \\
\text { controls }\end{array}$ & $\begin{array}{l}\text { Comparability } \\
\text { of cases and } \\
\text { controls on the } \\
\text { basis of design } \\
\text { or analysis }\end{array}$ & $\begin{array}{l}\text { Ascertainment } \\
\text { of exposure }\end{array}$ & $\begin{array}{l}\text { Same method of } \\
\text { ascertainment for } \\
\text { cases and controls }\end{array}$ & $\begin{array}{l}\text { Non- } \\
\text { response } \\
\text { rate }\end{array}$ & $\begin{array}{l}\text { Total } \\
\text { stars }\end{array}$ & $\begin{array}{l}\text { Risk of } \\
\text { bias }\end{array}$ \\
\hline Kawaguchi, T[19] & $*$ & * & - & $*$ & - & $*$ & $*$ & - & 5 & Moderate \\
\hline Bosco, J. L[21] & * & * & * & * & * & * & * & - & 7 & Low \\
\hline Monami, M[22] & $*$ & $*$ & - & $*$ & $*$ & $*$ & $*$ & - & 6 & Moderate \\
\hline Chang, C. H.[25] & $*$ & * & - & $*$ & $*$ & $*$ & $*$ & - & 6 & Moderate \\
\hline Origasa $H,[33]$ & * & - & - & * & $*$ & * & $*$ & - & 5 & Moderate \\
\hline Simo, R.[34] & * & - & * & * & $*$ & * & * & - & 6 & Moderate \\
\hline Dabrowski, M.[38] & * & - & - & * & ** & * & * & - & 6 & Moderate \\
\hline
\end{tabular}

risk, 4 demonstrated a decreased risk of cancer with AGI use [15, 28, 31, 36], 1 showed an increased risk [25], and 20 reported no significant relationship [16-24, 26, 27, 29, $30,32-35,37-39]$. A meta-analysis of the observational studies demonstrated that AGI use (as compared with nonuse) was associated with a statistically significant $14 \%$ reduction in cancer incidence $(n=21$ studies; odds ratio $[\mathrm{OR}]=0.86,95 \%$ CI $0.78-0.96$ ) (Figure 2). There was considerable heterogeneity between studies (Cochran Q test $P<0.01 ; I^{2}=82.4 \%$ ). Of the study characteristics assessed in meta-regression, the quality of study and adjustment for potential confounders were statistically significant $(P<0.01)$ (Table 3$)$. Meta-regression analysis did not show any significant effect size modification by other specific study characteristics considered, such as study design, setting, location, or duration of DM.

In subgroup analyses, the proactive association was detected in cohort studies, population-based studies, studies adjusting for covariates, Asian population, newonset diabetic patients, and studies with low risk of bias. The subgroup analyses suggested an increased risk in casecontrol studies and in studies not adjusted for potential confounders. Sufficient data were not available to analyze the impact of AGI dose and duration.

Meta-analysis of RCTs revealed no significant association of AGI with cancer risk ( $n=4$ studies; $\mathrm{OR}=$ $0.83,95 \%$ CI $0.20-3.46, I^{2}=0 \%$ ) (Figure S2). 
Table 3: Subgroup analysis

\begin{tabular}{|c|c|c|c|c|c|}
\hline Subgroups & No. of studies & OR & $95 \%$ CI & $\mathbf{I}^{2}$ & Meta-Regression $P$-Value \\
\hline Study design & & & & & 0.116 \\
\hline Cohort & 14 & 0.81 & $0.70-0.94$ & $84.6 \%$ & \\
\hline $\mathrm{C}-\mathrm{C}$ & 7 & 1.10 & $1.05-1.15$ & $0 \%$ & \\
\hline Study location & & & & & 0.409 \\
\hline Western & 5 & 0.99 & $0.97-1.00$ & $0 \%$ & \\
\hline Asian & 16 & 0.83 & $0.70-0.98$ & $86.5 \%$ & \\
\hline Study setting & & & & & 0.629 \\
\hline Hospital based & 6 & 0.91 & $0.72-1.16$ & $0 \%$ & \\
\hline Population based & 15 & 0.86 & $0.77-0.95$ & $87.3 \%$ & \\
\hline Quality of study & & & & & 0.000 \\
\hline Low risk of bias & 13 & 0.73 & $0.65-0.83$ & $25.3 \%$ & \\
\hline Moderate risk of bias & 8 & 1.03 & $0.95-1.11$ & $70.0 \%$ & \\
\hline Multivariate adjusted analysis & & & & & 0.007 \\
\hline Yes & 14 & 0.76 & $0.63-0.92$ & $84.5 \%$ & \\
\hline No & 7 & 1.08 & $1.04-1.13$ & $0 \%$ & \\
\hline Duration of DM & & & & & 0.577 \\
\hline New-onset & 10 & 0.80 & $0.66-0.97$ & $91.7 \%$ & \\
\hline Less than 10 years & 3 & 0.84 & $0.63-1.11$ & $0 \%$ & \\
\hline Moe than 10 years & 1 & 1.25 & $0.56-2.75$ & - & \\
\hline
\end{tabular}

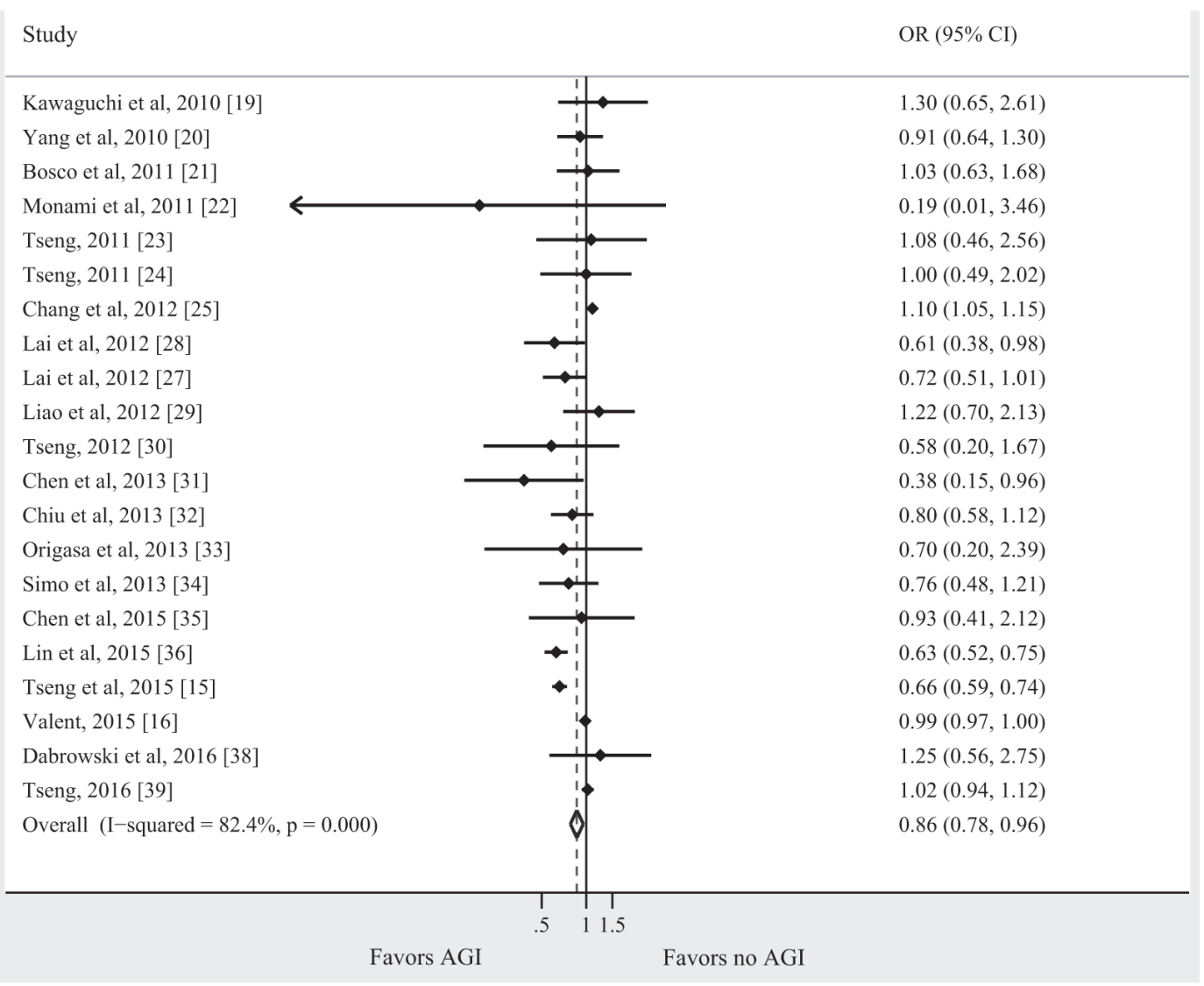

Figure 2: Summary of OR of observational studies assessing the risk of cancer with AGI use. 


\section{AGI and cancer risk for individual tumor types}

Seventeen studies (16 observational studies and 1 $\mathrm{RCT}$ ) reported the risk of cancer for individual tumor types in AGI users compared with non-users. The relationship between AGI use and risk for each tumor type is shown in Figure 3. As there were 4 Taiwanese studies on colorectal cancer from the same cohort $[15,25,32,36]$, the study with the largest cohort size was included [15]. Two studies

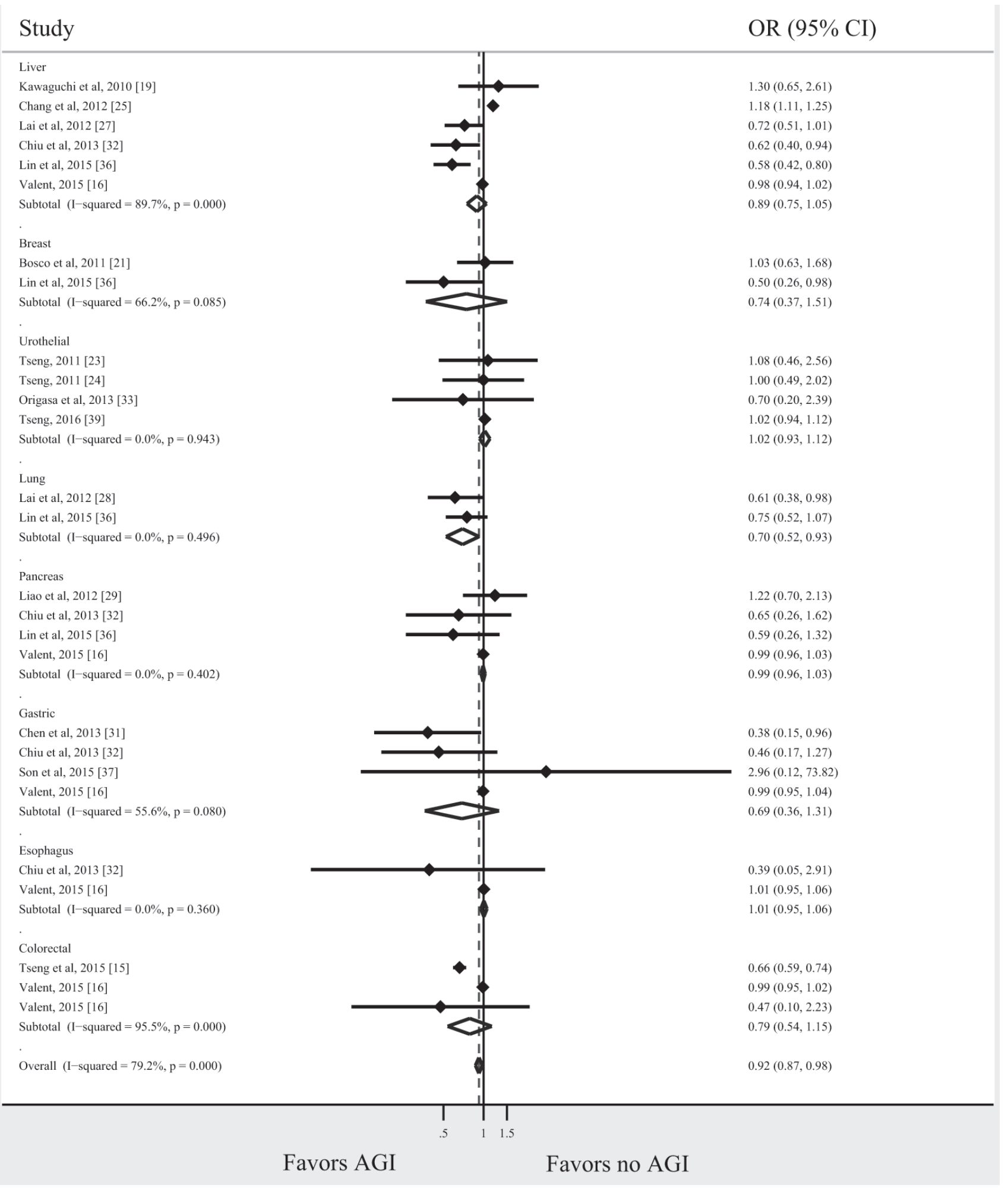

Figure 3: AGI and the cancer risk for individual tumor types. 
presented data on colon and rectum cancer separately, which were pooled to derive a summary estimate for the study [16, 32]. The association between AGI use and decreased risk of cancer was most prominent in patients with lung cancer ( $n=2$ studies; OR $=0.70,95 \%$ CI 0.52 $0.93, I^{2}=0 \%$ ). There was a slight trend toward lower risk of colorectal, liver, gastric, and breast cancer with AGI use $\left(\mathrm{OR}=0.79,95 \%\right.$ CI $0.54-1.15, I^{2}=96 \%$; OR $=0.89$, $95.5 \%$ CI $0.75-1.05, I^{2}=89.7 \%$; OR $=0.69,95 \%$ CI $0.36-1.31, I^{2}=55.6 \%$; OR $=0.74,95 \%$ CI $0.37-1.51, I^{2}=$ $66.2 \%$, respectively); however, these associations were not statistically significant. No significant associations were identified for pancreatic, esophageal, and urothelial cancer. A meta-analysis of studies of gastrointestinal cancer (Figure 4) showed a significant association between AGI use and reduced cancer risk $(\mathrm{OR}=0.83,95 \% \mathrm{CI} 0.71$ $\left.0.97, I^{2}=89.9 \%\right)$.

\section{Publication bias}

There was no evidence of significant publication bias, both quantitatively ( $P=1.0$ for Begg's test, $P=0.116$ for Egger's test) and qualitatively, on visual inspection of the funnel plot (Figure S3).

\section{DISCUSSION}

This study showed an overall reducing effect of AGI on cancer risk, which was inconsistent with the previous meta-analysis [7]. The previous meta-analysis noted a significantly increased risk with AGI only in the case-control studies, but not in the cohort studies or RCTs [7]. In addition, the meta-analysis included only two cohort studies and omitted important recent studies on the influence of AGI on cancer risk. Furthermore, subgroup analyses were not performed. In subgroup analyses of our present analysis, the association between AGI and cancer risk was more prominent in population-based studies, studies with low risk of bias, and studies adjusted for covariates, indicating that more prospective, well-designed studies are warranted to confirm the results.

Various explanations have been provided for the association between diabetes and cancer. Metformin has been shown to possess anti-cancer property both in vivo and in vitro [9]. It has been proposed that metformin exerts its anti-cancer properties through direct effects on cancer cells, particularly through inhibition of the AMPK/mTOR pathway, and indirect effects by decreasing glucose, insulin, insulin-like growth factor 1 (IGF-1) levels, and other inflammatory factors [9].

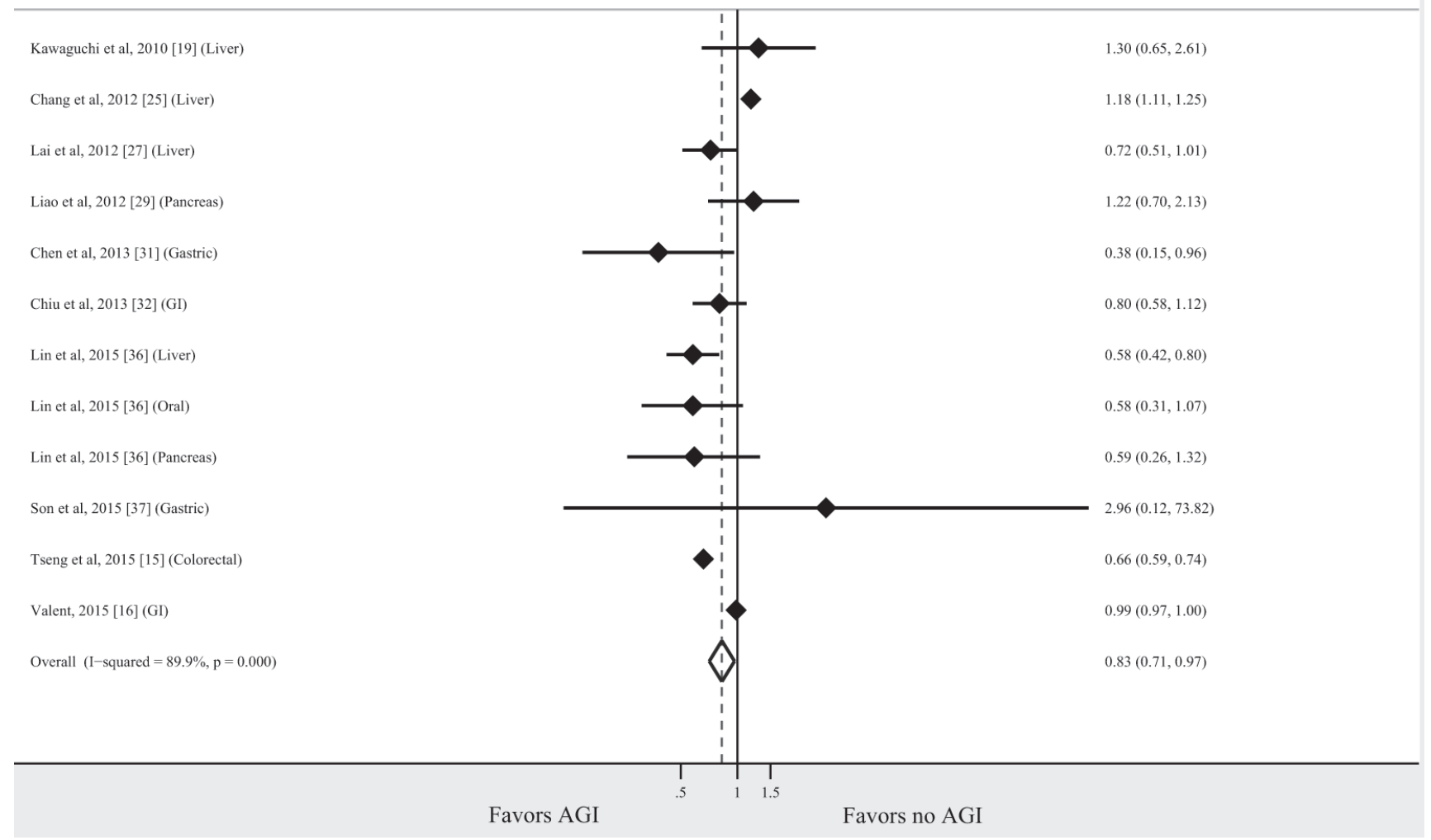

Figure 4: AGI and the risk for gastrointestinal cancer. 
Metformin is the only first-line oral ADM recommended by international guidelines for the treatment of type 2 diabetes [40]. AGI is another inexpensive and well-tolerated drug that has been widely used to treat DM for more than 20 years [41]. AGIs have shown better glucose-lowering effect in Asian populations than in Western populations [42], and acarbose has shown to exhibit an efficacy similar to that of metformin in China [43]. Yang et al showed that acarbose diminished insulin and glucagon concentrations while increasing GLP-1 concentration in Chinese type 2 diabetic patients [43]. A previous study also revealed that acarbose treatment reduced postprandial hyperinsulinemia [44].

Besides hypoglycemic effect, acarbose has been shown to possess anti-inflammatory and immunomodulatory effects in animal and human studies involving both Western and Asian type 2 DM patients [45-47]. Three mechanisms can be implicated for these actions. First, acarbose may regulate gut hormones. Previous studies demonstrated that acarbose use increased GLP-1 in the serum [43, 48-51]. Second, acarbose may interact with gut microbiota. A recent study found that acarbose increased the content of gut Bifidobacterium longum in type $2 \mathrm{DM}$ patients [47], which could help to reduce intestinal inflammation [52]. Third, the unabsorbed acarbose may have an effect on the intestinal immune system by suppressing pro-inflammatory cytokine expression in the gut [53].

Owing to the known effects of AGI on the gut, it can be hypothesized that AGI may modify the risk of gastrointestinal cancer. A study of transformed cells suggested that acarbose exerts antineoplastic effect by increasing butyrate production [54], which has protective effect against colonic cancer [55]. Previous studies suggested that fecal butyrate, which is a short-chain fatty acid, is a key colonocyte nutrient and an important survival factor for colonic epithelial cells [56]. Acarbose has been found to reduce the colonic transit time and thus change the fecal concentration of bile acids, which may have protective effect against colorectal cancer $[57,58]$. In addition, acarbose use has been found to be associated with increased production of GLP-1 [43, 48-51]. Previous studies indicated GLP-1 as a potent inducer of cAMP and an inhibitor of breast cancer cell proliferation [59]. A study using CT26 tumor-bearing BALB/c mice showed that GLP-1 receptor agonist treatment increased tumor apoptosis [60]. In the APC gene knockout animal model, which develops multiple intestinal adenomas, acarbose had a regressive effect on the size of gastrointestinal adenomas but did not significantly decrease the number of colonic neoplasms [61]. Most recently, a cohort study of DM patients in Taiwan showed that acarbose use reduced the risk of incident colorectal cancer in patients with diabetes in a dose-dependent manner [15]. Our analysis showed an overall reducing effect of AGI on gastrointestinal cancer risk. However, only a slight trend toward lower risk was observed in colorectal cancer, liver cancer, and gastric cancer, which was not statistically significant. It is difficult to identify the effects of AGI on gastrointestinal cancer based on retrospective studies due to confounding by indication and reverse causality. More prospective observational studies, which account for these sources of heterogeneity, would be required to truly assess the impact of AGI on the risk of gastrointestinal cancer.

Our analysis showed that AGI use was associated with a slightly decreased risk in patients with lung cancer ( $n=2$ studies; OR, 0.86; 95\% CI, 0.76-0.97). The associations observed between ADMs and lung cancer were not consistent [62-64]. The precise mechanism of the observed cancer risk reduction is not clear. The results of our analysis should be interpreted with caution as only two studies were included in the analysis.

The strengths of our study include the comprehensive and simultaneous assessment of the effects of AGI on the risk modification of cancer, and findings from multiple subgroup analyses to ensure stability of the association and identify factors responsible for heterogeneity.

There were also several limitations to our metaanalysis. First, the cancer-modifying association between AGI and cancer risk were based on data from observational studies, was apparent based on the RCT cases. In observational studies, random allocation of the intervention is not done, which is necessary to test the exposure-outcome hypothesis optimally. As a result, the chemopreventive effect of AGI seen in observational studies may be an overestimate of its true effect. However, we should acknowledge that the average follow-up time in observational studies is much longer than that in RCTs, which could explain why current clinical trials of AGI for the management of DM do not demonstrate a significant effect on cancer. Second, all studies were not adjusted for the same confounders. In addition, most patients with DM in these studies were on multiple ADMs simultaneously. As a result, as compared with patients on AGI, patients "not on AGI" (the comparator group) would be more likely to be on metformin. Therefore, it is difficult to interpret whether the risk modification inferred for any one agent is real or confounded by exposures to other ADMs. In the only monotherapy, population-based observational study conducted by Chen et al to compare cancer incidence with metformin and other ADMs in patients with DM, AGI use was not found to be associated with risk of cancer [35]. The true clinical effect of AGI on cancer risk should ideally be studied by comparing patients on AGI therapy for DM with those managed by non-medical/dietary therapy over an extended period of time.

In conclusion, meta-analysis of existing studies suggests a protective association between AGI use and risk of cancer in patients with DM. As there was 
considerable heterogeneity across studies, future, welldesigned, prospective studies are warranted to evaluate this association better.

\section{MATERIALS AND METHODS}

This systematic review was conducted following guidance provided by the Cochrane Handbook [65] and is reported according to the Preferred Reporting Items for Systematic Reviews and Meta-Analyses (PRISMA) guidelines [66].

\section{Data sources, searches, and study selection}

First, a systematic literature search of MEDLINE (1966 through September 30, 2016), EMBASE (1988 through September 30, 2016), and Web of Science (1993 through September 30, 2016) databases was conducted by two study investigators for all relevant articles on the association between AGI use and risk of cancer in patients with DM. The following keywords and/or corresponding $\mathrm{MeSH}$ terms were used: (acarbose OR voglibose OR miglitol OR alpha glucosidase inhibitor OR alpha glucoside hydrolase inhibitor OR $\alpha$ glucosidase inhibitor OR $\alpha$ glycoside hydrolase inhibitor) AND (cancer OR tumor OR neoplasm). The title and abstract of studies identified in the search were reviewed by two authors independently to exclude studies that did not answer the research question of interest. The full text of the remaining articles was examined to determine whether it contained relevant information. Next, bibliographies of the selected articles, as well as review articles on the topic were manually searched for additional articles. Third, manual search of abstracts from major endocrinology and oncology conferences (2007-2016) was performed for additional abstracts on the topic. When information available was not complete, attempts were made to contact the corresponding authors of the studies for additional information.

Studies considered in this meta-analysis were either observational studies or RCTs that met the following inclusion criteria: (1) evaluated and clearly defined exposure to AGI, (2) reported cancer outcomes in patients with DM, and (3) reported relative risks or odds ratio (OR) or provided data for their estimation. Inclusion was not otherwise restricted by study size, language, or publication type. When there were multiple publications from the same population, only data from the most comprehensive report were included. The flow diagram summarizing study identification and selection is shown in Figure 1.

\section{Data extraction and quality assessment}

Data were independently abstracted onto a standardized form by two reviewers. The following data were collected from each study: study design, time period of study/year of publication, location/setting of the population studied, type of DM, duration of DM, age/ sex of patients included, type of tumor, dose and duration of AGI use (if reported), information source of exposure ascertainment and outcome assessment, total number of persons, OR, and 95\% CI with and without adjustment for confounding factors. When data on individual tumor types were reported separately, we pooled these to derive a summary estimate for the study. For all analysis, referent group was composed of patients with DM not exposed to AGI. Conflicts in data abstraction were resolved by consensus, referring back to the original article.

Quality assessment for observational studies was performed using the Newcastle Ottawa scale [67]. A score of 7-9 represents low risk of bias, 4-6 represents moderate risk of bias, and 0-3 represents high risk of bias. The quality of RCTs was assessed using a revised form of Cochrane Collaboration's tool for assessing risk of bias in randomized trials [68]. This tool focuses on the adequacy of randomization and allocation concealment procedures, blinding, and loss to follow-up. Any discrepancies were addressed by a joint reevaluation of the original article.

\section{Data synthesis and analysis}

The primary analysis focused on assessing the relationship between AGI and risk of cancer in patients with DM. A priori hypotheses to explain potential heterogeneity in the direction and magnitude of effect among different observational studies included type of cancer, location/setting of study (Western population $v s$. Asian population; population based vs. hospital based), study design (case-control vs. cohort), quality of study (low bias vs. moderate bias vs. high bias), and whether the study was adjusted for the potential confounding factors. Because of significant differences in the design of observational studies and RCTs, data from these RCTs were analyzed and presented separately.

We used the random-effects model described by DerSimonian and Laird to calculate meta-analytic OR and 95\% CI [69]. Adjusted ORs reported in studies were used for analysis to account for confounding variables. We assessed heterogeneity between study-specific estimates with the Cochran $\mathrm{Q}$ statistic $(P<0.10)$ and $\mathrm{I}^{2}$ statistic $[69,70]$. Once heterogeneity was noted, between-study sources of heterogeneity were investigated using subgroup and meta-regression analyses by study characteristics (as described above). All $P$ values were two-tailed. For all tests (except for heterogeneity and publication bias), a $P$ value of less than 0.05 was considered statistically significant. Subgroup analysis was conducted on all relevant study characteristics regardless of statistical significance. We investigated the presence and the effect of publication bias using a combination of the Begg's test [70] and Egger's test [71]. Statistical analyses were 
performed using Stata 12.1 (StataCorp). An overview of the study protocol is provided in S1 Protocol.

\section{Abbreviations}

ADM, anti-diabetic medication; AGI, alphaglucosidase inhibitor; DM, diabetes mellitus; GLP-1, glucagon-like peptide-1; RCT, randomized controlled trial.

\section{Author contributions}

Conception and design: Y.M.Z. and Y.J.W.; data collection, analysis, and interpretation of the data: Y.M.Z., H.Y.L., and L.Z.S.; drafting of the manuscript: Y.M.Z.; critical revision: Y.M.Z. and Y.J.W. All authors read and approved the final version of the manuscript.

\section{ACKNOWLEDGMENTS}

We thank Dr. Pengfei Shan from Department of Endocrinology and Metabolism, Second Affiliated Hospital of Zhejiang University School of Medicine, China, for his constructive suggestions to improve the quality of this paper. We would also like to extend our gratitude to Prof. Giuseppe Derosa from Diabetes and Metabolic Diseases Unit, University of Pavia, Italy, who returned important information on request. This work was supported by Natural Science Foundation of Zhejiang Province.

\section{CONFLICTS OF INTEREST}

The authors declare that they have no conflicts of interest.

\section{FUNDING}

This work was supported by Natural Science Foundation of Zhejiang Province (grants LY14H160023).

\section{REFERENCES}

1. Vinicor F. The public health burden of diabetes and the reality of limits. Diabetes Care. 1998; 21 Suppl 3: C15-C18.

2. Whiting DR, Guariguata L, Weil C, Shaw J. IDF diabetes atlas: global estimates of the prevalence of diabetes for 2011 and 2030. Diabetes Res Clin Pract. 2011; 94: 311-321.

3. Yang W, Lu J, Weng J, Jia W, Ji L, Xiao J, Shan Z, Liu J, Tian H, Ji Q, Zhu D, Ge J, Lin L, et al. Prevalence of diabetes among men and women in China. N Engl J Med. 2010; 362: 1090-1101.

4. Vigneri R. Diabetes: diabetes therapy and cancer risk. Nat Rev Endocrinol. 2009; 5: 651-652.
5. Nicolucci A. Epidemiological aspects of neoplasms in diabetes. Acta Diabetol. 2010; 47: 87-95.

6. Giovannucci E, Harlan DM, Archer MC, Bergenstal RM, Gapstur SM, Habel LA, Pollak M, Regensteiner JG, Yee D. Diabetes and cancer: a consensus report. CA Cancer J Clin. 2010; 60: 207-221.

7. Wu L, Zhu J, Prokop LJ, Murad MH. Pharmacologic therapy of diabetes and overall cancer risk and mortality: a meta-analysis of 265 studies. Sci Rep. 2015; 5: 10147.

8. Coyle C, Cafferty FH, Vale C, Langley RE. Metformin as an adjuvant treatment for cancer: a systematic review and meta-analysis. Ann Oncol. 2016; 27: 2184-2195.

9. Daugan M, Dufay Wojcicki A, d'Hayer B, Boudy V. Metformin: an anti-diabetic drug to fight cancer. Pharmacol Res. 2016; 113: 675-685.

10. Nauck MA, Friedrich N. Do GLP-1-based therapies increase cancer risk? Diabetes Care. 2013; 36 Suppl 2: S245-S252.

11. Singh S, Singh PP, Singh AG, Murad MH, McWilliams RR, Chari ST. Anti-diabetic medications and risk of pancreatic cancer in patients with diabetes mellitus: a systematic review and meta-analysis. Am J Gastroenterol. 2013; 108: 510-519; quiz 20.

12. Lin HW, Tseng $\mathrm{CH}$. A review on the relationship between SGLT2 inhibitors and cancer. Int J Endocrinol. 2014; 2014: 719578 .

13. Davidson MB. Pioglitazone (Actos) and bladder cancer: legal system triumphs over the evidence. J Diabetes Complications. 2016; 30: 981-985.

14. Tseng CH. Sitagliptin and pancreatic cancer risk in patients with type 2 diabetes. Eur J Clin Invest. 2016; 46: 70-79.

15. Tseng YH, Tsan YT, Chan WC, Sheu WH, Chen PC. Use of an alpha-glucosidase inhibitor and the risk of colorectal cancer in patients with diabetes: a nationwide, populationbased cohort study. Diabetes Care. 2015; 38: 2068-2074.

16. Valent F. Diabetes mellitus and cancer of the digestive organs: an Italian population-based cohort study. J Diabetes Complications. 2015; 29: 1056-1061.

17. Nakamura T, Matsuda T, Kawagoe Y, Ogawa H, Takahashi Y, Sekizuka K, Koide H. Effect of pioglitazone on carotid intima-media thickness and arterial stiffness in type 2 diabetic nephropathy patients. Metabolism. 2004; 53: 13821386.

18. Pan C, Yang W, Barona JP, Wang Y, Niggli M, Mohideen $\mathrm{P}$, Foley JE. Comparison of vildagliptin and acarbose monotherapy in patients with Type 2 diabetes: a 24-week, double-blind, randomized trial. Diabet Med. 2008; 25: 435441.

19. Kawaguchi T, Taniguchi E, Morita Y, Shirachi M, Tateishi I, Nagata E, Sata M. Association of exogenous insulin or sulphonylurea treatment with an increased incidence of hepatoma in patients with hepatitis $\mathrm{C}$ virus infection. Liver Int. 2010; 30: 479-486.

20. Yang X, So WY, Ma RC, Yu LW, Ko GT, Kong AP, Ng 
VW, Luk AO, Ozaki R, Tong PC, Chow CC, Chan JC. Use of sulphonylurea and cancer in type 2 diabetes-The Hong Kong Diabetes Registry. Diabetes Res Clin Pract. 2010; 90: 343-351.

21. Bosco JL, Antonsen S, Sorensen HT, Pedersen L, Lash TL. Metformin and incident breast cancer among diabetic women: a population-based case-control study in Denmark. Cancer Epidemiol Biomarkers Prev. 2011; 20: 101-111.

22. Monami M, Colombi C, Balzi D, Dicembrini I, Giannini S, Melani C, Vitale V, Romano D, Barchielli A, Marchionni N, Rotella CM, Mannucci E. Metformin and cancer occurrence in insulin-treated type 2 diabetic patients. Diabetes Care. 2011; 34: 129-131.

23. Tseng $\mathrm{CH}$. Diabetes and risk of bladder cancer: a study using the National Health Insurance database in Taiwan. Diabetologia. 2011; 54: 2009-2015.

24. Tseng $\mathrm{CH}$. Diabetes and risk of prostate cancer: a study using the National Health Insurance. Diabetes Care. 2011; 34: 616-621.

25. Chang CH, Lin JW, Wu LC, Lai MS, Chuang LM, Chan KA. Association of thiazolidinediones with liver cancer and colorectal cancer in type 2 diabetes mellitus. Hepatology. 2012; 55: 1462-1472.

26. Kawamori R, Inagaki N, Araki E, Watada H, Hayashi N, Horie Y, Sarashina A, Gong Y, von Eynatten M, Woerle HJ, Dugi KA. Linagliptin monotherapy provides superior glycaemic control versus placebo or voglibose with comparable safety in Japanese patients with type 2 diabetes: a randomized, placebo and active comparator-controlled, double-blind study. Diabetes Obes Metab. 2012; 14: 348357.

27. Lai SW, Chen PC, Liao KF, Muo CH, Lin CC, Sung FC. Risk of hepatocellular carcinoma in diabetic patients and risk reduction associated with anti-diabetic therapy: a population-based cohort study. Am J Gastroenterol. 2012; 107: 46-452.

28. Lai SW, Liao KF, Chen PC, Tsai PY, Hsieh DP, Chen CC. Antidiabetes drugs correlate with decreased risk of lung cancer: a population-based observation in Taiwan. Clin Lung Cancer. 2012; 13:143-48.

29. Liao KF, Lai SW, Li CI, Chen WC. Diabetes mellitus correlates with increased risk of pancreatic cancer: a population-based cohort study in Taiwan. J Gastroenterol Hepatol. 2012; 27: 709-713.

30. Tseng $\mathrm{CH}$. Thyroid cancer risk is not increased in diabetic patients. PLoS One. 2012; 7: e53096.

31. Chen YL, Cheng KC, Lai SW, Tsai IJ, Lin CC, Sung FC, Lin CC, Chen PC. Diabetes and risk of subsequent gastric cancer: a population-based cohort study in Taiwan. Gastric Cancer. 2013; 16: 389-396.

32. Chiu CC, Huang CC, Chen YC, Chen TJ, Liang Y, Lin SJ, Chen JW, Leu HB, Chan WL. Increased risk of gastrointestinal malignancy in patients with diabetes mellitus and correlations with anti-diabetes drugs: a nationwide population-based study in Taiwan. Intern Med. 2013; 52: 939-946.

33. Origasa H, Lee SH, Nakagawa H, Kumagai N, Fuse H, Tobe K. Pioglitazone use and bladder cancer - hospitalbased results from a nested case-control study in Japan. Jpn Pharmacol Ther. 2013; 41: 5.

34. Simo R, Plana-Ripoll O, Puente D, Morros R, Mundet X, Vilca LM, Hernandez C, Fuentes I, Procupet A, Tabernero JM, Violan C. Impact of glucose-lowering agents on the risk of cancer in type 2 diabetic patients. The Barcelona case-control study. PLoS One. 2013; 8: e79968.

35. Chen YC, Kok VC, Chien CH, Horng JT, Tsai JJ. Cancer risk in patients aged 30 years and above with type 2 diabetes receiving antidiabetic monotherapy: a cohort study using metformin as the comparator. Ther Clin Risk Manag. 2015; 11: $1315-1323$.

36. Lin CM, Huang HL, Chu FY, Fan HC, Chen HA, Chu DM, Wu LW, Wang CC, Chen WL, Lin SH, Ho SY. Association between Gastroenterological Malignancy and Diabetes Mellitus and Anti-Diabetic Therapy: A Nationwide, Population-Based Cohort Study. PLoS One. 2015; 10: e0125421.

37. Son JW, Lee IK, Woo JT, Baik SH, Jang HC, Lee KW, Cha BS, Sung YA, Park TS, Yoo SJ, Yoon KH. A prospective, randomized, multicenter trial comparing the efficacy and safety of the concurrent use of long-acting insulin with mitiglinide or voglibose in patients with type 2 diabetes. Endocr J. 2015; 62: 1049-1057.

38. Dabrowski M, Szymanska-Garbacz E, Miszczyszyn Z, Derezinski T, Czupryniak L. Risk factors for cancer development in type 2 diabetes: a retrospective case-control study. BMC Cancer. 2016; 16: 785.

39. Tseng $\mathrm{CH}$. Use of metformin and risk of kidney cancer in patients with type 2 diabetes. Eur J Cancer. 2016; 52: 19-25.

40. Inzucchi SE, Bergenstal RM, Buse JB, Diamant M, Ferrannini E, Nauck M, Peters AL, Tsapas A, Wender R, Matthews DR. Management of hyperglycaemia in type 2 diabetes: a patient-centered approach. Position statement of the American Diabetes Association (ADA) and the European Association for the Study of Diabetes (EASD). Diabetologia. 2012; 55: 1577-1596.

41. Rosak C, Mertes G. Critical evaluation of the role of acarbose in the treatment of diabetes: patient considerations. Diabetes Metab Syndr Obes. 2012; 5: 357-367.

42. Zhu Q, Tong Y, Wu T, Li J, Tong N. Comparison of the hypoglycemic effect of acarbose monotherapy in patients with type 2 diabetes mellitus consuming an Eastern or Western diet: a systematic meta-analysis. Clin Ther. 2013; 35: 880-899.

43. Yang W, Liu J, Shan Z, Tian H, Zhou Z, Ji Q, Weng J, Jia W, Lu J, Liu J, Xu Y, Yang Z, Chen W. Acarbose compared with metformin as initial therapy in patients with newly diagnosed type 2 diabetes: an open-label, non-inferiority randomised trial. Lancet Diabetes Endocrinol. 2014; 2: 46- 
55.

44. Inoue I, Takahashi K, Noji S, Awata T, Negishi K, Katayama S. Acarbose controls postprandial hyperproinsulinemia in non-insulin dependent diabetes mellitus. Diabetes Res Clin Pract. 1997; 36: 143-151.

45. Derosa G, Maffioli P, Ferrari I, Fogari E, D'Angelo A, Palumbo I, Randazzo S, Bianchi L, Cicero AF. Acarbose actions on insulin resistance and inflammatory parameters during an oral fat load. Eur J Pharmacol. 2011; 651: 240250.

46. Chen HH, Chen DY, Chao YH, Chen YM, Wu CL, Lai $\mathrm{KL}$, Lin $\mathrm{CH}$, Lin CC. Acarbose decreases the rheumatoid arthritis risk of diabetic patients and attenuates the incidence and severity of collagen-induced arthritis in mice. Sci Rep. 2015; 5: 18288 .

47. Su B, Liu H, Li J, Sunli Y, Liu B, Liu D, Zhang P, Meng X. Acarbose treatment affects the serum levels of inflammatory cytokines and the gut content of bifidobacteria in Chinese patients with type 2 diabetes mellitus. J Diabetes. 2015; 7 : 729-739.

48. Groop PH, Groop L, Totterman KJ, Fyhrquist F. Effects of acarbose on the relationship between changes in GIP and insulin responses to meals in normal subjects. Acta Endocrinol (Copenh). 1986; 112: 361-366.

49. Qualmann C, Nauck MA, Holst JJ, Orskov C, Creutzfeldt W. Glucagon-like peptide 1 (7-36 amide) secretion in response to luminal sucrose from the upper and lower gut. A study using alpha-glucosidase inhibition (acarbose). Scand J Gastroenterol. 1995; 30: 892-896.

50. Enc FY, Imeryuz N, Akin L, Turoglu T, Dede F, Haklar G, Tekesin N, Bekiroglu N, Yegen BC, Rehfeld JF, Holst JJ, Ulusoy NB. Inhibition of gastric emptying by acarbose is correlated with GLP-1 response and accompanied by CCK release. Am J Physiol Gastrointest Liver Physiol. 2001; 281: G752-G763.

51. Zheng MY, Yang JH, Shan CY, Zhou HT, Xu YG, Wang Y, Ren HZ, Chang BC, Chen LM. Effects of 24-week treatment with acarbose on glucagon-like peptide 1 in newly diagnosed type 2 diabetic patients: a preliminary report. Cardiovasc Diabetol. 2013; 12: 73.

52. Jeon SG, Kayama H, Ueda Y, Takahashi T, Asahara T, Tsuji H, Tsuji NM, Kiyono H, Ma JS, Kusu T, Okumura $\mathrm{R}$, Hara H, Yoshida H, et al. Probiotic Bifidobacterium breve induces IL-10-producing Tr1 cells in the colon. PLoS Pathog. 2012; 8: e1002714.

53. Zhang Q, Xiao X, Li M, Li W, Yu M, Zhang H, Wang Z, Xiang H. Acarbose reduces blood glucose by activating miR-10a-5p and miR-664 in diabetic rats. PLoS One. 2013; 8: e79697.

54. Weaver GA, Tangel CT, Krause JA, Parfitt MM, Stragand JJ, Jenkins PL, Erb TA, Davidson RH, Alpern HD, Guiney WB Jr, Higgins PJ. Biomarkers of human colonic cell growth are influenced differently by a history of colonic neoplasia and the consumption of acarbose. J Nutr. 2000;
130: $2718-2725$

55. Holt PR, Atillasoy E, Lindenbaum J, Ho SB, Lupton JR, McMahon D, Moss SF. Effects of acarbose on fecal nutrients, colonic $\mathrm{pH}$, and short-chain fatty acids and rectal proliferative indices. Metabolism. 1996; 45: 1179-1187.

56. Hague A, Singh B, Paraskeva C. Butyrate acts as a survival factor for colonic epithelial cells: further fuel for the in vivo versus in vitro debate. Gastroenterology. 1997; 112: 10361040.

57. Ron Y, Wainstein J, Leibovitz A, Monastirsky N, Habot B, Avni Y, Segal R. The effect of acarbose on the colonic transit time of elderly long-term care patients with type 2 diabetes mellitus. J Gerontol A Biol Sci Med Sci. 2002; 57 : M111-M114.

58. Potter JD. Reconciling the epidemiology, physiology, and molecular biology of colon cancer. JAMA. 1992; 268: 1573-1577.

59. Ligumsky H, Wolf I, Israeli S, Haimsohn M, Ferber S, Karasik A, Kaufman B, Rubinek T. The peptide-hormone glucagon-like peptide-1 activates cAMP and inhibits growth of breast cancer cells. Breast Cancer Res Treat. 2012; 132: 449-461.

60. Koehler JA, Kain T, Drucker DJ. Glucagon-like peptide-1 receptor activation inhibits growth and augments apoptosis in murine CT26 colon cancer cells. Endocrinology. 2011; 152: 3362-3372.

61. Quesada CF, Kimata H, Mori M, Nishimura M, Tsuneyoshi T, Baba S. Piroxicam and acarbose as chemopreventive agents for spontaneous intestinal adenomas in APC gene 1309 knockout mice. Jpn J Cancer Res. 1998; 89: 392-396.

62. Nie SP, Chen H, Zhuang MQ, Lu M. Anti-diabetic medications do not influence risk of lung cancer in patients with diabetes mellitus: a systematic review and metaanalysis. Asian Pac J Cancer Prev. 2014; 15: 6863-6869.

63. Wu Y, Liu HB, Shi XF, Song Y. Conventional hypoglycaemic agents and the risk of lung cancer in patients with diabetes: a meta-analysis. PLoS One. 2014; 9: e99577.

64. Zhu N, Zhang Y, Gong YI, He J, Chen X. Metformin and lung cancer risk of patients with type 2 diabetes mellitus: a meta-analysis. Biomed Rep. 2015; 3: 235-241.

65. Cochrane Handbook for Systematic Reviews of Interventions. In: Higgins J, PT. and Green S, eds. The Cochrane Collaboration; 2011.

66. Moher D, Liberati A, Tetzlaff J, Altman DG. Preferred reporting items for systematic reviews and meta-analyses: the PRISMA statement. PLoS Med. 2009; 6: e1000097.

67. Wells G, Shea B, O’Connell D, Peterson J, Welch V, Losos M, Tugwell P. The Newcastle-Ottawa Scale (NOS) for assessing the quality of nonrandomized studies in metaanalyses. 2013.

68. Higgins JP, Altman DG, Gotzsche PC, Juni P, Moher D, Oxman AD, Savovic J, Schulz KF, Weeks L, Sterne JA. The Cochrane Collaboration's tool for assessing risk of bias in randomised trials. BMJ. 2011; 343: d5928. 
69. DerSimonian R, Laird N. Meta-analysis in clinical trials. Control Clin Trials. 1986; 7: 177-188.

70. Higgins JP, Thompson SG. Quantifying heterogeneity in a meta-analysis. Stat Med. 2002; 21: 1539-1558.
71. Egger M, Davey Smith G, Schneider M, Minder C. Bias in meta-analysis detected by a simple, graphical test. BMJ. 1997; 315: 629-634. 